\title{
Doctors in Court, Honour, and Professional Ethics: Two Scandals in Imperial Germany*
}

Andreas-Holger Maehle

\section{Summary}

Comparing two public medical affairs which involved disciplinary proceedings and libel actions, one from Bavaria and one from Prussia, this article analyzes the dynamics behind legal conflicts over doctors' professional ethics in Imperial Germany. In both the case of Dr Maurice Hutzler, who committed suicide after conflicts with senior colleagues at the Gisela Children's Hospital and a sentence of the court of honour of the Munich Medical District Society, and the Berlin "patient trade" affair, in which the medical professors Ernst von Leyden, Hermann Senator, Karl Anton Ewald and Carl Posner were accused of having made payments to middlemen for bringing them lucrative private patients, notions of personal and professional honour played a central role. The Munich case highlighted shortcomings of the Bavarian medical court of honour system, which was less developed than its Prussian counterpart. The analysis of the two cases suggests that the ethics of medical practice in early twentieth-century Germany should be viewed as part of a culture of honour.

Keywords: medical courts of honour; professional ethics; disciplinary proceedings; libel trials; Imperial Germany

* I gratefully acknowledge the support of my research by the Wellcome Trust as part of a Strategic Award on the theme "Knowledge, Ethics and Representation of Medicine and Health: Historical Perspectives". I would further like to thank Sebastian Pranghofer for his efficient research assistance and the audiences of the workshop "Legal Medicine and Expertise in History" (4 December 2009) at Oxford Brookes University and the Philosophy Department's "Research Away Day" (21 June 2010) at Durham University as well as the anonymous referees for Gesnerus for their helpful comments on an earlier version of this paper.

Prof. Dr. med. Andreas-Holger Maehle, PhD, Centre for the History of Medicine and Disease, Wolfson Research Institute, Durham University, Queen's Campus, Stockton TS17 6BH, United Kingdom (a.h.maehle@durham.ac.uk). 


\section{Introduction}

Medical ethics and medical law are nowadays often seen as twin fields: the former dealing with the moral basis of medicine, the latter with the legislation and case law pertaining to medical practice, both with a view to ensure correct, "professional" conduct of doctors and others working in the health sector. ${ }^{1}$ The fact that these fields are also historically related is well known: the Manchester physician Thomas Percival (1740-1804), who in 1803 introduced the term "Medical Ethics" into English discourse with his book of the same title, had initially circulated a draft of his work among colleagues and friends under the heading "Medical Jurisprudence" (1794). In Percival's view, which referred back to Justinian law, jurisprudence included moral injunctions as well as positive ordinances. ${ }^{2}$ However, historical research has paid relatively little attention to the relationships between ethics and law in medicine. Rather, historiography has tended to focus either on the development of legal (forensic) medicine and the role of scientific expertise in the court room, ${ }^{3}$ or on the history of medical ethics as such. ${ }^{4}$

Certain exceptions to this dichotomy are the studies that have addressed a phenomenon which is positioned between morality and law - the phenomenon of "honour". Much of the work in this field has focused on the history of the duel, but more recently honour conflicts in everyday life and their consequences in court proceedings have been given attention as well. ${ }^{5}$ Regarding the notion of honour in medical practice I refer here especially to the research of Robert Nye on honour codes of French doctors around 1900. Nye has argued that medical deontology, i.e. the system of doctors' ethical duties, in late nineteenth-century France was developed on the basis of traditional, pre-revolutionary male codes of honour and chivalry, which had been adapted to the requirements of bourgeois society. In a competitive environment medical societies or "syndicates" voluntarily adopted codes of conduct and set up "chambers of discipline". Such means of professional selfregulation helped doctors to maintain relative independence from the state. ${ }^{6}$

1 Hope/Savulescu/Hendrick 2003; Pattison 2009; Mason/Laurie 2009.

2 Leake 1975, xxiii; Pickstone 1993, 169.

3 Clark/Crawford 1994; Jasanoff 1995; Goold/Kelly 2009; Watson 2011.

4 Baker/Porter/Porter 1993; Baker 1995; Wear/Geyer-Kordesch/French 1993; Schomerus 2001; Maehle/Geyer-Kordesch 2002; Baker/McCullough 2009.

5 Major historical studies on honour codes in German respectively French society are: Frevert 1995; McAleer 1994; Goldberg 2010; Nye 1993. For a recent philosophical perspective on the phenomenon of honour, see Appiah 2010. For a review of historical and sociological literature on honour, see Vogt 1997. The notion that honour is located "between" morality and law goes back to Georg Simmel (1858-1918), see Simmel 1958, 403.

6 Nye 1995. 
As my own work on medical ethics in Imperial Germany has shown, codifications of professional medical conduct were likewise important in the German context, but even more so were - especially in Prussia - the so-called "medical courts of honour" (ärztliche Ehrengerichte). Modelled upon the disciplinary tribunals for lawyers and the military, they had been introduced in Prussia by law in 1899 and been attached to the official medical chambers (Ärztekammern). As in France, competition for patients, in a period of relative "overcrowding" of the medical profession, was the most relevant background to the formation of these disciplinary tribunals. Their task was to investigate and discipline cases of professional misconduct. The criteria according to which they judged were whether a doctor's behaviour was compatible with professional dignity and reputation, and whether a doctor practised conscientiously. The membership of the Prussian medical courts of honour included medical doctors, jurists, and government officials. Disciplinary measures comprised warnings, reprimands, fines, and withdrawal of the voting rights for the medical chamber. As an appellate court, the Prussian Court of Honour for Doctors (Preussischer Ehrengerichtshof für Ärzte) was established in Berlin. It was chaired by a legally trained government official and had a membership of four doctors delegated by the medical chambers and two doctors appointed by the King. Bavaria did not introduce such a formalized and state-authorized court of honour system until 1927, but in the 1890s the Bavarian medical district societies had voluntarily formed their own courts of honour, which were composed only of medical doctors as judges. ${ }^{7}$ This difference in the composition and status of the tribunals in Prussia and Bavaria turned out to be relevant in the cases that I am going to discuss in this article.

Professional ethics, codes of honourable conduct, and quasi legal structures of control and discipline thus formed the matrix in which medical conflicts were acted out. Among the most common disciplinary offences were excessive advertising, financial misconduct, slander or libel, "lack of collegiality", unfair competition, and sexual offences. ${ }^{8}$ The attractiveness of medical discipline consisted for the profession in the possibility of solving conflicts among doctors and cases of misconduct towards patients largely intra muros, even in Prussia, without alerting the general public. Damage to the reputation of the profession might thus be avoided. However, such quiet

7 Maehle 2009, 6-46.

8 See Maehle 2009,37, for a list of reasons for disciplinary punishments by the medical court of honour for Brandenburg and Berlin between 1903 and 1920. A similar spectrum of issues was reflected in the published decisions of the court of appeal, the Prussian Court of Honour for Doctors; see ibid., 38, for the period 1900-1914; and Rabi 2002, 56f., for the Prussian and for the Saxon Court of Honour for Doctors in the period 1918-1933. 
internal resolution of conflicts did not always succeed. In this article I will analyze two, roughly simultaneous cases - one from Bavaria and one from Prussia - in which conflicts exceeded the internal professional sphere and put, as it were, a bright spotlight on how strongly doctors' behaviour was steered by their understanding of personal and professional honour. The cases will moreover illustrate how also the general courts were used by doctors, through private libel actions, to defend their honour. While the two selected cases are exceptional in how extensively they are documented in the archival sources of the involved institutions and in the coverage by the contemporary medical and daily press, they are representative regarding the accusations of misconduct. The first case, from Bavaria, concerned charges of lack of collegiality and of offending against good faith; and the second case, from Prussia, was concerned with accusations of unfair competition for patients and alleged financial misconduct. The two cases are complementary in covering different aspects of medical practice. The first case, which occurred in Munich, pertained to the charitable, institutional practice of medical specialists (who had their separate private practices as their source of income). Conversely, the second case, from Berlin, referred to the private practice of medical professors, carried out in public institutions, the university clinics, alongside their duties in teaching, research and institutional patient care.

\section{The case of Dr Hutzler in Munich}

Under the heading "A Victim of the Medical Court of Honour" the newspaper Münchener Post reported on 4 April 1907 about the death of the young paediatrician Maurice Hutzler, who had been acting director of the Gisela Children's Hospital in Munich-Schwabing. ${ }^{9}$ On 31 March, in the evening of Easter Sunday, he had committed suicide by a pistol shot into his heart. He was just 34 years old. What had happened?

Only in November 1906 Dr Hutzler had shown the German Empress, Auguste Victoria, around the Gisela Children's Hospital, a charitable institution that was also supported by the Town of Munich and whose board of governors was composed of members of Munich's high society. The Empress had been accompanied by the hospital's patroness, Princess Gisela of

9 «Ein Opfer des ärztlichen Ehrengerichts», Münchener Post, 4 April 1907, 6f. See also «Selbstmord», Münchener Zeitung, 2 April 1907, 4; «Der Selbstmord Dr. M. Hutzler», ibid., 3 April 1907,4f.; «Die Vorgänge im Gisela-Kinderspital», Münchner Neueste Nachrichten, 4 April 1907, Vorabendblatt. 
Bavaria, daughter of the Austrian Emperor Franz Joseph. The imperial visit seemed to have gone well according to the daily press: the German Empress informed herself about the training of nurses, personally lifted children out of their beds, and inspected the hospital's exemplary "milk kitchen". After having signed the guestbook, she expressed her fullest satisfaction with the hospital and its management. ${ }^{10}$

But, beneath the surface, things were not well. Hutzler had joined the hospital in 1901 as an assistant to Drs Rudolf Hecker and Joseph Trumpp, who had founded the hospital two years earlier as an outpatient clinic. The young doctor showed such enthusiasm for his work that he soon seemed to run the place on his own. In 1906 this was acknowledged by appointing Hutzler as an equal co-director of the by now fully developed paediatric hospital, within an annual rotation system with the other two doctors. However, tensions between Hutzler and his two senior colleagues grew as the latter felt increasingly sidelined. As witnesses later stated, the situation deteriorated after the visit of the Empress, who was initially led by Hutzler through the hospital while the two older doctors stood back. A serious crisis occurred in mid-December 1906 when Hutzler dismissed a female doctor without consulting his two colleagues. Shortly afterwards, Hecker and Trumpp declared to the board of governors that they could no longer work with Hutzler, whose "nervousness", they claimed, made any collaboration impossible. At some stage in the conflict between the doctors, Trumpp had even challenged Hutzler to a duel, but Hutzler had declined, saying that if he fought a duel he would do it seriously and he did not want to make Trumpp's children (whom he knew as patients) fatherless. Hecker in particular was also concerned that Hutzler had sometimes resorted to physical punishment of unruly children. ${ }^{11}$ Hutzler, who admittedly had led the hospital to success and recognition, was now supposed to leave.

The board of governors, after investigation by a sub-committee, acknowledged that Hutzler might be a difficult personality, but did not find reasons to dismiss him or to make changes to the hospital's management. In protest, Hecker and Trumpp resigned from their hospital posts before Christmas 1906 - and retracted their resignation immediately after Christmas, having taken legal advice. However, the board of governors, chaired by Under Secretary of State Georg von Mayr, confirmed Hutzler as director, also for the year 1907 - which would have been the year of Dr Trumpp's directorship

10 «Besuch der Kaiserin in Münchner humanitären Anstalten», Münchner Neueste Nachrichten, 14 November 1906, Morgenblatt, 2.

11 «Gerichtssaal. Dr. Quidde und der Aerztliche Bezirksverein München», Münchner Neueste Nachrichten, 1 December 1907, 2f.; and 3 December 1907, 11, 13. 
under the rotation system. At this point, Drs Hecker and Trumpp brought charges against Hutzler in front of the court of honour of the Munich Medical District Society. Hutzler, they claimed, had recklessly and in an unsporting manner used the board's decision to "push" them out of the very hospital that they themselves had founded. On 30 January 1907, the three judges of the court of honour, medical doctors Kastl, Jooss and Daxenberger, issued their verdict: Hutzler was "guilty of a serious offence against the duties of collegiality" ("eines schweren Verstosses gegen die kollegialen Anstandspflichten schuldig"). Moreover, they concluded that he had violated through his current behaviour "also in a general civil sense the principle of good faith" ("auch nach allgemein bürgerlichen Begriffen Treu und Glauben verletzt"). Especially, this latter part of the verdict turned out to be important, because it could be - and was - read as denying Hutzler's civil honour. The court of honour demanded of Hutzler that he resigned from his directorship of the hospital and made way for Dr Trumpp. ${ }^{12}$

Hutzler was deeply upset by this verdict, which he regarded as wrong and unjust. In March he circulated a printed, 16-page open letter to the court of honour, in which he defended in detail his conduct and announced his resignation from the hospital to which he had "devoted five years of [his] life exclusively and without pay". ${ }^{13}$ At the general meeting of the Munich Medical District Society, held on 23 March 1907, the verdict and Hutzler's open letter were controversially discussed. Hutzler himself had cancelled his membership of the district society and was thus not present. Dr Kastl, who was simultaneously the chairman of the society, admitted that he, personally, had not intended to call Hutzler's honour into question. But, since the other two honour judges were not present at this society meeting, he refused to make a general declaration of honour for Hutzler at this time. Through a medical friend, Dr Wacker, who had defended Hutzler at the court of honour, Hutzler was informed about the contents of the society meeting and apparently waited for the official declaration from the three honour judges - but it did not come. A week later, Hutzler shot himself. ${ }^{14}$

The suicide of Dr Hutzler catapulted the issues in the Gisela Children's Hospital into the public domain. The "tragic case of Dr Hutzler", as it soon became known, was widely reported in the Munich newspapers. ${ }^{15}$ Hutzler had

12 Cf. Maurice Hutzler, «An das Schieds- (Ehren-) Gericht des ärztlichen Bezirksvereins München», StadtA Mü, Krankenhaus Schwabing, Nr. 40, 2-6.

13 Ibid., 16.

14 «Aus ärztlichen Standesvereinen. Aerztlicher Bezirksverein München. Mitgliederversammlung am Samstag, den 23. März 1907», Münchener Medizinische Wochenschrift 54 (1907) 701. «Tagesgeschichtliche Notizen», ibid., 758f.

15 See note 9 above. 
not just been any young hospital doctor. He was the son of the then wellknown writer Sarah Hutzler (1853-1893), and his stepfather was the famous actor Josef Kainz (1858-1910). Justizrat Max Bernstein (1854-1925), a prominent Munich lawyer and author, had been a fatherly friend of the family since Maurice Hutzler's boyhood. The hospital's board of governors stepped down. Princess Gisela retracted her patronage. Drs Hecker and Trumpp declared that they would no longer be available for the directorship of the hospital. Eventually, a new board of governors appointed a new director from outside. ${ }^{16}$

However, the Hutzler case was more than a scandal in Munich society. Significantly for our interest in the relations between medical ethics and the law, the court of honour itself came under attack. Dr Wacker claimed to have found documents among Hutzler's papers that proved his dead friend's innocence ${ }^{17}$ Led by the historian and liberal Member of Parliament (Landtag) Ludwig Quidde (1858-1941), the local councillors of Schwabing submitted on 11 April 1907 an official inquiry to the municipal authorities about the future of the Gisela Children's Hospital and about how the interests and reputation of the town would be protected. In their inquiry Quidde and his co-signatories, including Dr Wacker and other medical doctors, claimed that the court of honour proceedings had driven Dr Hutzler to suicide ("das Verfahren vor dem Ehrengericht des ärztlichen Bezirksvereins [...], das Dr. Hutzler in den Tod getrieben hat"). ${ }^{18}$ Incensed about this allegation, the council of the Munich Medical District Society demanded that the medical local councillors retract it - otherwise, the court of honour would be taking steps against them. The councillors refused, denying that the court of honour had a right to judge their actions as representatives of the town. ${ }^{19}$ Quidde repeated the accusation in a newspaper, the Münchner Neueste Nachrichten, adding that the court of honour had been "grossly negligent". In his view, the court's verdict constituted a "thoughtless and unjustified destruction" of Hutzler's honour. ${ }^{20}$

16 See StadtA Mü, Krankenanstalten, Nr. 171; Ratssitzungsprotokolle, Film 523/2 Sitzungsprotokolle des Magistrats, April-Juni 1907; «Die Generalversammlung des Gisela-Kinderspitalvereins», Münchner Neueste Nachrichten, 19 April 1907,3.

17 Nassauer 1907a, 916.

18 Gemeinde-Bevollmächtigten-Collegium, «Anfrage an den Magistrat. Betreff Stellung des Magistrats zum Gisela-Kinderspital-Verein», Munich, 11 April 1907, StadtA Mü, Krankenhaus Schwabing, Nr. 40, fol. 17-21. On Quidde's political work in Munich, see Holl 2007, 126-143.

19 Vorstandschaft des Aerztlichen Bezirksvereins, «Erklärung», Münchener Zeitung, 15 April 1907, 5; Dr Wacker, Dr von Pfistermeister, Dr A. Krüche, Dr Heigl, Dr Kolbeck, «Erklärung», Munich, 18 April 1907, StadtA Mü, Krankenhaus Schwabing, Nr. 40, fol. 22; «Vom GiselaKinderspital», Münchner Neueste Nachrichten, 19 April 1907, 4.

20 Quidde in Münchner Neueste Nachrichten, 16 April 1907, Vorabendblatt, 4. 
Clearly, the court of honour now had to act to defend its honour. The three judges, Drs Kastl, Jooss and Daxenberger, started a private libel action against Quidde. In late November and early December 1907 the newspapers reported in detail about the trial, which was well attended by Munich's high society. Justizrat Bernstein served as the defence lawyer for Quidde. Only on the surface was this trial about whether Quidde had offended the three doctors of the court of honour. The chairman of the court of lay assessors (Schöffengericht) made it his task to assess how and on which evidential basis exactly the judges of the medical court of honour had arrived at their verdict against Dr Hutzler. This meant that the whole Hutzler case was unfolded again in public. Hecker, Trumpp and other hospital personnel as well as members of the board of governors were questioned as witnesses. At stake was the rehabilitation of the dead doctor's honour. A major weakness of the medical court of honour - which was emphasized in the libel trial - was that its bylaws had only permitted medical doctors as witnesses. In the case against Hutzler, however, it would have been crucial to have heard evidence from the members of the hospital's board of governors who were all lay persons. Moreover, it turned out that the court of honour had not produced official minutes of the proceedings, although a female stenographer had taken notes. After the third day of the libel trial, the plaintiffs Drs Kastl, Jooss and Daxenberger realized that they were going to lose the case and withdrew their charges against Quidde. The three court of honour judges declared that they would not have said in their verdict that Hutzler offended against good faith if they had had the evidence that was made available at this libel trial. ${ }^{21}$

Despite the fact that he had been the defendant, Quidde was outraged, because he had lost the public platform of the trial to posthumously rehabilitate Hutzler. ${ }^{22}$ While the withdrawal of the charges probably prevented further damage to the plaintiffs' public reputation, their own district society did not take this step well: the three doctors, it was felt, should have defended themselves to the end against Quidde's accusations. ${ }^{23}$ Already before the trial

21 «Das ärztliche Ehrengericht», Münchener Post, 30 November 1907, 6; 1 December 1907, 6; 3 December 1907, 6; «Der Rückzug der Ehrenrichter», ibid., 4 December 1907, 5; «Ein Nachspiel zur Affäre Dr. Hutzler», Münchener Zeitung, 28 November 1907, 5; 29 November 1907, 7; 30 November 1907, 9; «Dr. Quidde und der Aerztliche Bezirksverein München», Münchner Neueste Nachrichten, 29 November 1907, 3; 30 November 1907, 4; 1 December 1907, 2f.; 3 December 1907, Vorabendblatt, 11, 13 and Morgenblatt, 3; 4 December 1907, 3. See also StadtA Mü, Chronik der Stadt München, Film 198, fol. 3426-3451, 3453-3461, 3475-3501, 3545-3550.

22 See the declaration by Quidde in «Dr. Quidde und der Aerztliche Bezirksverein München», Münchner Neueste Nachrichten, 6 December 1907, 3; and «Der ärztliche EhrengerichtsProzeß», Münchener Post, 7 December 1907, 6.

23 «Tagesgeschichtliche Notizen», Münchener Medizinische Wochenschrift 54 (1907) 2557. 
against Quidde, Kastl had announced that he was no longer available for the chairmanship of the society and of the court of honour, and also the other two honour judges, Jooss and Daxenberger, had resigned. Kastl had been replaced as society chairman by a doctor who had no involvement in the Hutzler case. ${ }^{24}$

In the aftermath of the case, there were loud calls for a reform of the Bavarian medical court of honour system. Like in Prussia, jurists should be included among the members of these professional courts and mechanisms should be introduced to hear not just doctors, but also lay people, as witnesses. ${ }^{25} \mathrm{In}$ fact proposals for a new court of honour system were considered and prepared in the Bavarian Ministry of the Interior during the following years, but the outbreak of the First World War prevented legislation. ${ }^{26}$ Only in the Weimar Republic, in 1927, were changes introduced that included legally trained members in the Bavarian courts of honour and set up a central appeals court, similar to the Prussian system. ${ }^{27}$

For us, the whole affair of the Gisela Children's Hospital illustrates the contemporary obsession with personal as well as professional honour in the predominantly male medical profession. Hecker and Trumpp felt offended as Hutzler ignored their claims for recognition as senior colleagues. Hutzler felt deeply insulted by the court of honour verdict that apparently denied his civil honour. And the honour judges themselves were offended by the allegation that their proceedings had driven Hutzler to his suicide. According to Georg Simmel's sociological theory, honour strengthens the cohesion of social groups. ${ }^{28}$ But, as this example has shown, honour conflicts had also a destructive potential (also in a time when duels had been made illegal ${ }^{29}$ ) and were not necessarily resolved through disciplinary tribunals or the courts.

24 Nassauer 1907b, 1156f.; «Tagesgeschichtliche Notizen», Münchener Medizinische Wochenschrift 54 (1907) 1158f.

25 Grassmann 1907; «Tagesgeschichtliche Notizen», Münchener Medizinische Wochenschrift 54 (1907) 2509; Mayer 1908; Doerfler 1908.

26 See Maehle 2009, 29f.; «Entwurf eines Gesetzes über die Standesvertretung, die Standespflichten und das ehrengerichtliche Verfahren der Ärzte», BayHStA, MJu, Nr. 15367.

27 The new medical professional courts (ärztliche Berufsgerichte) in Bavaria, one in each of the governmental districts, were composed of four doctors and one legally trained member. An appellate court (Landesberufungsgericht) consisting of five doctors and two professional judges was established in Munich. See Finkenrath 1928, 51f.; Herold-Schmidt 1997, 53. For details of the Prussian system, which included from the beginning legally trained as well as medical members, both at the level of the regional courts of honour and at the level of the central appellate court in Berlin, see Maehle 1999 and Maehle 2009, 19.

28 Simmel 1958,326,403-405. For a discussion of Simmel's conception of honour, see Vogt 1997, 153-186.

29 See Frevert 1995, 28-35; McAleer 1994, 21-28. Duelling continued to be a common practice during the Kaiserreich, although it was punishable under the Reich Criminal Code (Strafgesetzbuch) of 1871. 
To use Pierre Bourdieu's concept, honour constituted important "social and symbolic capital". ${ }^{30}$ If a gentleman's honour was questioned or denied, this was a very serious matter that demanded consequences. In the case of Hutzler the consequence was suicide. The case also illustrates that expertise in questions of professional ethics stood on shaky grounds: the medical court of honour judges of the Munich Medical District Society became targets of serious criticism from within the profession as well as from the public. My second example, from Prussia, where the disciplinary system was more developed at the time, will show some similar features but also significant differences.

\section{The Berlin "patient trade" scandal}

In October 1908 the Medical Society of Berlin-Schöneberg started an investigation of referrals of foreign private patients to specialist consultants in the hospitals and university clinics. The main target of this investigation was the Russian Institute for Medical Consultations, run by doctors Semjon Lipliawsky and Siegfried Weissbein, who arranged for Russian patients visiting the capital consultations with specialists. They also performed preliminary diagnostics, prepared the case histories for the consultants, and helped out as interpreters. ${ }^{31}$ There were other such "institutes" and individual agents in Berlin, who offered similar services for foreign visitors. It was estimated that about 60000-70000 Russian patients per year came to Berlin in order to consult medical specialists. ${ }^{32}$ Allegedly, the middlemen were not only paid by the patients but also by the consulted clinicians. For the medical practitioners of Schöneberg this would constitute unfair competition for lucrative private patients. Through a series of appeals in the Berliner Ärzte-Correspondenz (i.e. the official newsletter of the Berlin medical chamber), the deputy chairman of the Schöneberg medical society, Julius Friedemann, called for information on such practices, "in the interest of the professional dignity (Standeswürde) of the German and especially the Berlin medical profession" ${ }^{33}$ Clearly, the intention was to initiate disciplinary proceedings against consultants who made underhand

30 See Bourdieu 1972. Bourdieu's understanding of honour is discussed in Vogt 1997, 104-152.

31 Lipliawski 1901.

32 «Kleine Mittheilungen», Deutsche Medicinische Wochenschrift 27 (1901) 420.

33 «Tagesgeschichtliches. Verein der Schönebeger Aerzte E.V.», Berliner Ärzte-Correspondenz 13 (1908) 180. See also ibid., 192, 212. «Institute für medizinische Konsultationen», ibid., 213-215; «Weiteres über Institute für medizinische Konsultationen», Berliner Ärzte-Correspondenz 14 (1909) 10-12. 
payments to middlemen for bringing them private patients. The prominent Berlin neurologist Albert Moll (1862-1939), who ran a private practice at the Kurfürstendamm, became soon involved in this campaign. Moll was chairman of the so-called Fünfzehnerausschu $\beta$, a committee representing the interests of the medical profession in the area of Berlin. Moreover, in 1902 he had published a 650-page handbook of medical ethics and could thus claim a certain expertise in this field. ${ }^{34}$ Moll sided with Friedemann in the campaign against underhand payments by consultants and also collected himself "material" on this matter, which he partly shared with Friedemann.

The explosive nature of the issue became quickly apparent, as Ernst von Leyden (1832-1910), the doyen of internal medicine and former director of the First Medical Clinic of the Charite-Hospital of Berlin University, had agreed to be a consultant for a planned outpatient clinic of the Russian Institute for Medical Consultations. After Friedemann and Moll had personally spoken with him, von Leyden publicly retracted from this agreement. ${ }^{35}$ Soon, however, another prominent clinician, Karl Anton Ewald (1845-1915), director of the department for internal medicine at the AugustaHospital in Berlin and professor at Berlin University, came under suspicion to be involved in the "patient trade". Such a suspicion was all the more delicate, as Ewald was at the time a candidate in the elections for the council of the prestigious Berlin Medical Society (Berliner Medizinische Gesellschaft). As in the case of von Leyden, private conversations took place. On behalf of Ewald, Hermann Senator (1834-1911), the chairman of the Berlin Medical Society and director of the Third Medical Clinic and Outpatient Clinic (Poliklinik) of the Charité, followed Moll's invitation to speak with him and Friedemann about the matter at Moll's home. As Senator later claimed, Moll and Friedemann "tricked" him at this occasion to implicate himself in the dubious practices surrounding Russian private patients. The contents of the conversation became public in a libel trial in May 1909, after Senator had been accused in an article of the newspaper Berliner Zeitung am Mittag, in March 1909, of making payments to agents who sent their Russian clients to his clinic. ${ }^{36}$ As Moll later revealed as a witness in disciplinary pro-

\section{Moll 1902.}

35 «Tagesgeschichtliches. Poliklinik für Russen», Berliner Ärzte-Correspondenz 13 (1908) 184. 36 «Patientenfang. Professoren als Provisionsgeber», B. Z. am Mittag, 22 March 1909; «Verhandlung in der Privatklage des Geheimen Medizinalrats Professors Dr. Senator gegen den verantwortlichen Redakteur der 〈B. Z. am Mittag〉 «Dr. Fritz Auer vor der 147. Abteilung des Amtsgerichts Berlin-Mitte (Schöffengericht)», 11 May 1909, GStA PK, I. HA, Rep. 76, Va, Sekt.2,Tit.IV,Nr.46, Adh B:Disziplinaruntersuchungsakten gegen Ewald und Genossen, Mai-Juni 1909, fol. 101-201. The trial ended with a settlement. 
ceedings against Ewald, he also had, in early January 1909, a private conversation about the issue with the latter. ${ }^{37}$

Before the private libel action of Senator against the editor of the newspaper, however, further revelations about the patient trade and the Russian Institute for Medical Consultations had been made in a libel action of Moll against Dr Albert Levin, a member of the Schöneberg Medical Society, in March 1909. Levin belonged to the society's committee that had taken on the investigations in the "patient trade" matter. When Levin asked Moll to give him access to all his collected material on this issue, Moll refused. Incensed about this lack of collaboration, Levin wrote a letter to Moll, in which he accused him of cowardice or of holding back with the material for improper reasons, or of actually having no further material at all. Moll reacted with a private libel action against Levin. Initially, Moll had taken the view that one should deal discreetly with the patient trade issue, in order to stop abuses but not to expose individual colleagues. However, by the time of the trial against Levin his tactics had clearly changed. Moll now used the trial to publicize the conduct of the Berlin professors, and Friedemann became his ally in this enterprise. In his witness statement, Friedemann reported that von Leyden, Senator, and the urologist Carl Posner (1854-1928), who was an extraordinary professor at Berlin University, had admitted to have offered or made payments to middlemen from the Russian Institute for Medical Consultations or other agents that had brought them private patients. He also mentioned Ewald's name in this connection. The judge, keen to limit proceedings to the specific issue of libel, concluded that the described payments had actually happened, that Moll had made material on this matter available to Friedemann, and that the tone of Levin's letter to Moll was libellous. Levin was convicted to a 30 Mark fine. ${ }^{38}$

Both Moll and Levin subsequently appealed against this verdict. The appeal proceedings, held in late May 1909, shortly after the libel trial of Senator versus the editor of the Berliner Zeitung am Mittag (in which Moll appeared as a witness), provided a further forum to divulge details. This time, Moll's lawyer submitted an extensive motion to take evidence, in which he gave further details about the Berlin medical professors' relationships with the Russian Institute. Weissbein, as one of the Institute's directors, had a

37 GStA PK, I. HA, Rep. 76, Va, Sekt. 2, Tit. IV, Nr. 46, Adh B, fol. 91r-92v; 234r (statements of Moll on 10 May 1909 and 7 June 1909).

38 «Öffentliche Sitzung des Königlichen Schöffengerichts. Berlin-Schöneberg. Abt. 20. Privatklagesache des Sanitätsrats Dr. Albert Moll [...] gegen den prakt. Arzt Dr. Albert Levin», 20 March 1909, GStA PK, I. HA, Rep. 76, Va, Sekt. 2, Tit. IV, Nr. 46, Adh B, fol. 13r-14v, and [Urteil], 20 March 1909, fol. 15r-18r; «Der Prozess betr. die russischen Konsultationsbureaus», Berliner Ärzte-Correspondenz 14 (1909) 67f. 
defensive letter read out at the trial, in which he suggested that Moll and Levin had stage-managed the whole libel case to obtain a public platform for their accusations against the professors and the Institute. Both Moll and Levin energetically protested against this insinuation. The trial ended with a settlement: Levin acknowledged that Moll had had honourable reasons not to release his substantial material, withdrew the accusations that he had made against Moll in his letter, and took on the costs for the trial. Moll accepted and withdrew his action. ${ }^{39}$

The details of the trials were not only reported and commented upon in the medical press, such as the Berliner Ärzte-Correspondenz and the Berliner Klinische Wochenschrift, but also in newspapers across the political spectrum. ${ }^{40}$ The allegations that prominent members of the Berlin medical establishment had paid "bribes" or "commissions" to get private patients provided the right sort of material for a public scandal. Also anti-Semitic comments were made. The Deutsche Tageszeitung and Das Reich emphasized that Jewish doctors were prominently involved in the affair. ${ }^{41}$

The matter was also mentioned in the lower house of the Prussian Parliament, and the Ministry for Religious, Educational and Medical Affairs promised to investigate the allegations. At their own request, disciplinary proceedings were started against the professors Ewald, Senator and Posner. ${ }^{42}$ Weissbein as well as Friedemann initiated medical court of honour proceedings against themselves in order to have their conduct vindicated. In fact both their trials ended with an acquittal. ${ }^{43}$ In the disciplinary proceedings against the three professors, Moll was heard four times as a witness by the Univer-

39 «Zwei Beleidigungsprozesse betr. die Russischen Konsultationsbureaus», Berliner ÄrzteCorrespondenz 14 (1909) 113-116; «Tagesgeschichte.Vermittlung russischer Konsultationen», Zeitschrift für ärztliche Fortbildung 6 (1909) 399f.

40 See Kohn 1909; «Die russischen Konsultationen vor Gericht», Medizinische Reform 17 (1909) 133-135; «Die russischen Konsultationen. Die Rechtfertigung Senators», ibid., 231-238; «Die Russischen Konsultationen. Die Berufungsverhandlung Moll gegen Levin», ibid., 257-259; «Vermittlung russischer Konsultationen», Zeitschrift für ärztliche Fortbildung 6 (1909) 238f.; «Patientenfang. Schmiergelder von Berliner Aerzten», Berliner Tageblatt, 21 March 1909; «Russische Institute für medizinische Konsultationen und angebliche Schmiergelder von Professoren und anderen Aerzten», Vossische Zeitung, Zwölfte Beilage, 21 March 1909; «Patientenschacher vor Gericht», Die Post, 21 March 1909; «Krankenschacher», Tägliche Rundschau, 21 March 1909; «Aerztliche Schmiergelder», Berliner Tageblatt, 22 March 1909; «Patientenschacher», Der Montag. Berliner Lokal-Anzeiger, 22 March 1909; «Patientenfang. Professoren als Provisionsgeber», Berliner Abendpost, 23 March 1909.

41 «Patientenhandel», Deutsche Tageszeitung, 22 March 1909; «Schmiergelder», Das Reich, 23 March 1909; «Kleine Pfeile», Das Reich, 9 April 1909

42 Stenographische Berichte über die Verhandlungen des Preußischen Hauses der Abgeordneten, 21. Legislaturperiode, II. Session 1908/09, vol. 4, cols 5553-5554, 5625-5626.

43 GStA PK, I. HA, Rep. 76, Va, Sekt. 2, Tit. IV, Nr. 46, Adh A: Acta betr. den angeblichen Patientenhandel durch Ärzte und Professoren an der hiesigen Universität, fol. 152r-155r, $233 r-236 r$. 
sity judge, Daude. The Minister for Religious, Educational and Medical Affairs, to whom reports on the hearings were sent, admonished Daude to obtain more detailed evidence from Moll, because the latter initially refused to confirm that the accused professors had paid the middlemen specifically for bringing patients. Only after Daude threatened legal action against Moll himself if he refused to give full evidence, did Moll provide further details that incriminated Ewald and Posner. ${ }^{44}$ In the end, however, none of the involved professors were found guilty. While it was noted that the medical professors concerned had occasionally given money to agents who had brought them patients, the Ministry accepted their justification that these payments had just been small tips or small rewards for having acted as interpreters or for having assisted when the Russian patients were seen and examined by the professors. The disciplinary proceedings against Senator and Ewald were abandoned in November 1909, as were proceedings against von Leyden that had only been initiated in the previous month. ${ }^{45}$ Posner was acquitted in January $1910 .{ }^{46}$

With his intervention in this issue of professional conduct, Moll had established himself as an "expert" in medical ethics, but clearly at a reputational cost. While his name was now all over the newspapers and he had turned himself into a champion of the economic interests of Berlin's medical practitioners, his relationship to university medicine had suffered serious damage. For example, in the widely reported libel trial of Senator against the Berliner Zeitung am Mittag, Senator sneeringly called Moll and Friedemann "those two gentlemen, who make their appearance as guardians of medical ethics and of collegiality". ${ }^{47}$ And the young doctor and medical journalist Hans Lungwitz (1881-1967), who had recently completed his medical training in Ewald's department, published a series of polemic and ironic articles about the affair in his weekly Therapeutische Rundschau, in which he ridiculed Moll as "God's ethicist" and as a "medical Sherlock Holmes" who had "interrogated" the professors in his flat.Lungwitz also shared Weissbein's suspicion that the Moll versus Levin libel trial had been staged by these two in order to go public with their allegations. More generally, Lungwitz complained that the system of disciplinary tribunals had created a culture in which unhindered practising had become virtually impossible for doctors. ${ }^{48}$

44 GStA PK, I. HA, Rep. 76, Va, Sekt. 2, Tit. IV, Nr. 46, Adh B, fol. 91r-94v, 202r-203r, 211r, 233r-235r.

45 GStA PK, I. HA, Rep. 76, Va, Sekt, 2, Tit. IV, Adh A, fol. 275r-277v, 280r-282r.

46 Ibid., fol. 306r-326v.

47 GStA PK, I. HA, Rep. 76, Va, Sekt. 2, Tit. IV, Adh B, fol. 147 («[...] die beiden Herren, die als Wächter der medizinischen Ethik und der Kollegialität auftreten»).

48 Lungwitz 1909. On Lungwitz's biography and work, see Fellermeyer 2004; Miener 2005; Fischbach 2006. 


\section{Conclusions}

Like the Munich case of Dr Hutzler, this Berlin example illustrates for us how notions of personal and professional honour determined medical conflicts and how legal proceedings at various levels could arise from such conflicts. The four university professors felt offended by the allegations of Moll and the practitioners of the Schöneberg Medical Society. Moll felt insulted by Levin, who had questioned his trustworthiness. Weissbein felt unfairly treated as someone accused of improper practices; and Friedemann, as a key source of the accusations, had to defend his honour for making them. Libel trials were used to restore violated honour, but also to bring alleged misconduct within medical practice to the attention of the public, without giving oneself the image of an informer who denounced colleagues. This Prussian case, however, at the same time indicates the relative strength of an established system of medical courts of honour and disciplinary tribunals. The medical practitioners Friedemann and Weissbein initiated court of honour proceedings against themselves to clear their names; and Senator, Ewald and Posner, who as professors came under the disciplinary authority of the University and the Royal Disciplinary Court for Civil Servants, likewise asked themselves for disciplinary proceedings in order to officially prove their innocence. The eventual abandonment of the proceedings, respectively the acquittals, brought in fact a kind of closure to the whole affair - a significant difference to the court of honour proceedings against Hutzler in Munich. Here the weaknesses of the less stringent Bavarian medical court of honour system had been exposed - through the judges' unsure use of legal language in their verdict, their inability to hear non-medical witnesses, and their neglect of formal record keeping - which led to debates about a reform.

Other significant differences existed between the two cases. The Hutzler case was about treating colleagues with respect and in turn being treated respectfully, thus essentially about issues of power. In the Berlin "patient trade" affair, financial interests were at the heart of the conflict, besides the reputational damage to the medical professors if they had been found guilty of having paid commissions to agents. Such commercial behaviour was regarded as incompatible with the dignity of the medical profession. ${ }^{49}$ The much more personalized honour issues in the Munich case may go some way to explain its tragic outcome, Hutzler's suicide, whereas questionable and

49 The ideal of the economically disinterested doctor appears to have been still relevant in the most recent "patient trade" affair in Germany, in late summer 2009, concerning medical practitioners' taking of bonus payments for referring patients to particular hospitals. See Maehle 2010. 
potentially dishonourable conduct in financial matters in the Berlin case gave more room for interpretation, which was reflected in the acquittals. Yet, the Munich case was probably more typical in that the dispute moved from the "internal", professional court of honour to the public court of a libel trial. The Berlin affair was unusual in being initiated through a libel trial (Moll versus Levin), followed by proceedings of the professional disciplinary tribunals. The fact as such that in honour conflicts libel trials occurred in combination with disciplinary proceedings, is not surprising, however. As Ann Goldberg has recently shown, private actions (Privatklagen) for insults and defamation, under $\$ \$ 185-187$ of the Reich Criminal Code (Strafgesetzbuch), were ubiquitous in the modernizing society of Imperial Germany: in "politics, business, the Churches, professions, press, daily life, gender and labor relations". ${ }^{50}$ The notion of honour, far from being outdated, found new applications in the libel actions of citizens who wanted to assert their rights.

Moreover, in both the Munich and the Berlin case, libel trials appear to have been instrumentalized beyond their purpose of seeking redress for defamation. Quidde was not only defending himself against the libel charges of the three doctors of the Munich Medical District Society, but also tried to restore the honour of the dead Dr Hutzler in the public of a court room. He may also have welcomed the opportunity for yet another attack on the medical establishment. In the late 1890s Quidde had been a key figure in the public campaign against dangerous experiments on hospital patients without consent; and he and his wife, Margarete Quidde, were active in the contemporary anti-vivisection movement. ${ }^{51}$ Friedemann and Moll seemed to have used the publicity of the libel trial against Levin to hit a different target, i.e. the professors suspected to be involved in the "patient trade". Another similarity between the two cases exists in that those who prominently appeared as "guardians" of medical ethics, Moll in Berlin and Kastl in Munich, did not enhance their own reputation through their actions. For Kastl, the Hutzler affair led to the end of his chairmanship of the Munich Medical District Society; and Moll had made no friends for himself among Berlin's university professors - probably one of the reasons why he did not even achieve a titular professorship, despite his scientific contributions to the nascent fields of medical psychology and sexology. ${ }^{52}$ The status of the medical ethics expert was obviously a precarious one.

Historiographically, the two examined affairs illustrate how an analysis of honour conflicts and disciplinary cases can shed light on the motivations

50 Goldberg 2010, 9, 33, 37-80.

51 Elkeles 2004, 24.

52 See Maehle 2007; Maehle and Sauerteig (forthcoming). 
that drove doctors' behaviour towards their colleagues. Such an analysis can thus go substantially beyond the discussion of written ethical codes. Medical professionally ethics, at least in the period of Imperial Germany, is probably best understood as part of a culture of honour.

\section{Bibliography}

\section{Archival Sources}

Bayerisches Hauptstaatsarchiv, München (BayHStA): MJu, Nr. 15367

Geheimes Staatsarchiv Preussischer Kulturbesitz, Berlin (GStA PK):

I. HA, Rep. 76, Va, Sekt. 2, Tit. IV, Nr. 46, Adh A: Acta betr. den angeblichen Patientenhandel durch Ärzte und Professoren an der hiesigen Universität

I. HA, Rep. 76, Va, Sekt. 2, Tit. IV, Nr. 46, Adh B: Disziplinaruntersuchungsakten gegen Ewald und Genossen, Mai-Juni 1909

Stadtarchiv München (StadtA Mü):

Chronik der Stadt München, Film 198

Krankenanstalten, Nr. 171

Krankenhaus Schwabing, Nr. 40

Ratssitzungsprotokolle, Film 523/2: Sitzungsprotokolle des Magistrats, April-Juni 1907

\section{References}

Appiah, Kwame Anthony, The Honor Code: How Moral Revolutions Happen (New York 2010)

Baker, Robert (ed.), The Codification of Medical Morality, vol. 2: Anglo-American Medical Ethics and Medical Jurisprudence in the Nineteenth Century (Dordrecht 1995)

Baker, Robert/Dorothy Porter/Roy Porter (eds), The Codification of Medical Morality, vol. 1: Medical Ethics and Etiquette in the Eighteenth Century (Dordrecht 1993)

Baker, Robert B./Laurence B. McCullough (eds), The Cambridge World History of Medical Ethics (Cambridge 2009)

Bourdieu, Pierre, Esquisse d'une théorie de la pratique. Précédé de trois études d'ethnologie kabyle (Geneva 1972)

Clark, Michael/Catherine Crawford (eds), Legal Medicine in History (Cambridge 1994)

Doerfler, Hans, «Verbesserung oder Neuorganisation unserer bayerischen ärztlichen Ehrengerichte?», Münchener Medizinische Wochenschrift 55 (1908) 1997-1998

Elkeles, Barbara, "The German Debate on Human Experimentation between 1880 and 1914”, in: Volker Roelcke/Giovanni Maio (eds), Twentieth Century Ethics of Human Subjects Research: Historical Perspectives on Values, Practices, and Regulations (Stuttgart 2004), 19-33

Fellermeyer, Anika, Der Arzt Hans Lungwitz (1881-1967) im Spiegel seiner sozialreformerischen Schriften (MD thesis, Universität Würzburg 2004)

Finkenrath, K., Die Organisation der deutschen Ärzteschaft. Eine Einführung in die Geschichte und den gegenwärtigen Aufbau des wissenschaftlichen, standes- und wirtschaftspolitischen ärztlichen Vereinslebens (Berlin 1928)

Fischbach, Christine, Die Psychobiologie des Hans Lungwitz (1881-1967) im Spiegel der Rezensionen (MD thesis, Universität Würzburg 2006)

Frevert, Ute, Men of Honour: A Social and Cultural History of the Duel, translated by Anthony Williams (Cambridge 1995)

Goldberg, Ann, Honor, Politics, and the Law in Imperial Germany, 1871-1914 (Cambridge 2010) 
Goold, Imogen/Catherine Kelly (eds), Lawyers' Medicine. The Legislature, the Courts and Medical Practice, 1760-2000 (Oxford 2009)

Grassmann, «Aus ärztlichen Standesvereinen. Neuer Standesverein Münchener Aerzte. Sitzung vom 4. Dezember 1907», Münchener Medizinische Wochenschrift 54 (1907) 25072508

Herold-Schmidt, Hedwig, «Ärztliche Interessenvertretung im Kaiserreich 1871-1914», in Robert Jütte (ed.), Geschichte der deutschen Ärzteschaft. Organisierte Berufs- und Gesundheitspolitik im 19. und 20. Jahrhundert (Köln 1997), 43-95

Holl, Karl, Ludwig Quidde (1858-1941). Eine Biografie (Düsseldorf 2007)

Hope, Tony/Julian Savulescu/Judith Hendrick, Medical Ethics and Law. The Core Curriculum (Edinburgh 2003)

Jasanoff, Sheila, Science at the Bar: Law, Science, and Technology in America (Cambridge, Mass. 1995)

Kohn, Hans, «Russische Konsultationen», Berliner Klinische Wochenschrift 46 (1909) 623-624, 955-956, 1050-1051

Leake, Chauncey D. (ed.), Percival's Medical Ethics (Huntington, New York 1975)

Lipliawski, Semjon, «Das russische Institut für medizinische Consultationen zu Berlin in den ersten vier Monaten seines Bestehens», Deutsche Medicinische Wochenschrift 27 (1901) 697-698

Lungwitz, Hans, «Zu den medizinischen Wirren», Therapeutische Rundschau 3 (1909) 257-262, 289-292, 337-341, 353-356, 369-374, 424-425, 472

Maehle, Andreas-Holger, “Albert Moll”, in: William F. Bynum/Helen Bynum (eds), Dictionary of Medical Biography (Westport, Conn. 2007), vol. 4, 884-885

Maehle, Andreas-Holger, Doctors, Honour and the Law: Medical Ethics in Imperial Germany (Basingstoke 2009)

Maehle, Andreas-Holger, "patient trade' in Germany: an ethical issue at the practitioner-clinician interface in 1909 and 2009", Medical Humanities 36 (2010) 84-87

Maehle, Andreas-Holger, "Professional Ethics and Discipline: The Prussian Medical Courts of Honour, 1899-1920", Medizinhistorisches Journal 34 (1999) 309-338

Maehle, Andreas-Holger/Johanna Geyer-Kordesch (eds), Historical and Philosophical Perspectives on Biomedical Ethics: From Paternalism to Autonomy? (Aldershot 2002)

Maehle, Andreas-Holger/Lutz Sauerteig (eds), Sexology, Medical Ethics and Occultism: Albert Moll (1862-1939) and his Context (Medical History, special issue, forthcoming)

Mason, John Kenyon/Graeme T. Laurie (eds), Mason and McCall Smith's Law and Medical Ethics, $8^{\text {th }}$ edn (Oxford 2009)

Mayer, Wilhelm, «Zur Verbesserung unserer bayerischen ärztlichen Ehrengerichte», Münchener Medizinische Wochenschrift 55 (1908), 1788-1790

McAleer, Kevin, Dueling: The Cult of Honor in Fin-de-Sciècle Germany (Princeton 1994)

Miener, Matthias, Hans Lungwitz (1881-1967) - Arzt und Schriftsteller (MD thesis, Universität Würzburg 2005)

Moll, Albert, Ärztliche Ethik. Die Pflichten des Arztes in allen Beziehungen seiner Thätigkeit (Stuttgart 1902)

Nassauer, Max, «Aus ärztlichen Standesvereinen. Aerztlicher Bezirksverein München. Mitgliederversammlung vom 20. April 1907», Münchener Medizinische Wochenschrift 54 (1907a) 915-917

Nassauer, Max, «Aus ärztlichen Standesvereinen. Aerztlicher Bezirksverein München. Mitgliederversammlung vom 25. Mai 1907», Münchener Medizinische Wochenschrift 54 (1907b) $1156-1157$

Nye, Robert, "Honor Codes and Medical Ethics in Modern France", Bulletin of the History of Medicine 69 (1995) 91-111

Nye, Robert A., Masculinity and Male Codes of Honor in Modern France (New York 1993)

Pattison, Shaun D., Medical Law and Ethics, $2^{\text {nd }}$ edn (London 2009)

Pickstone, John V., "Thomas Percival and the Production of Medical Ethics", in: Robert Baker/Dorothy Porter/Roy Porter (eds), The Codification of Medical Morality, vol. 1: Medical Ethics and Etiquette in the Eighteenth Century (Dordrecht 1993), 161-178

Rabi, Barbara, Ärztliche Ethik - Eine Frage der Ehre? Die Prozesse und Urteile der ärztlichen Ehrengerichtshöfe in Preußen und Sachsen 1918-1933 (Frankfurt/Main 2002) 
Schomerus, Georg, Ein Ideal und sein Nutzen: Ärztliche Ethik in England und Deutschland 1902-1933 (Frankfurt/Main 2001)

Simmel, Georg, Soziologie. Untersuchungen über die Formen der Vergesellschaftung $\left[1^{\text {st }}\right.$ edn 1908], $4^{\text {th }}$ edn (Berlin 1958)

Vogt, Ludgera, Zur Logik der Ehre in der Gegenwartsgesellschaft. Differenzierung, Macht, Integration (Frankfurt/Main 1997)

Watson, Katherine D., Forensic Medicine in Western Society: A History (Abingdon 2011)

Wear, Andrew/Johanna Geyer-Kordesch/Roger French (eds), Doctors and Ethics: The Earlier Historical Setting of Professional Ethics (Amsterdam 1993)

\section{Newspapers}

Berliner Abendpost

Berliner Tageblatt

B. Z. am Mittag

Das Reich

Der Montag. Berliner Lokal-Anzeiger

Deutsche Tageszeitung

Die Post

Münchner Neueste Nachrichten

Münchener Post

Münchener Zeitung

Tägliche Rundschau

Vossische Zeitung

\section{Medical Periodicals}

Berliner Ärzte-Correspondenz

Berliner Klinische Wochenschrift

Deutsche Medicinische Wochenschrift

Medizinische Reform

Münchener Medizinische Wochenschrift

Therapeutische Rundschau

Zeitschrift für ärztliche Fortbildung 